\title{
A Study on Bearing Liabilities of Tourism Contract in Performance
}

\author{
Jian-gang QUAN ${ }^{1, a,{ }^{*}}$ \\ ${ }^{1}$ Law School, Renmin University of China, Beijing, 100872, China \\ ${ }^{2}$ Teaching Affairs Division, Hainan Vocational College of Political Science and Law, \\ Haikou, Hainan, 571100, China \\ aquanjiangang@126.com
}

Keywords: Tourism Contract, The Assistant Performer, Liability for Breach of Contract, Liability of Compensation for Mental Damage caused by Breach of Contract.

\begin{abstract}
The legal relationship of personal injury caused by the assistant performer in the tourism contract is complicated, which involves the multi-party legal body such as the tourism business operator, the assistant performer and the tourist, and the contractor may fulfill the liability for breach of contract and tort, and the blemish assured responsibility and other responsibilities. From the scenic area, public transport operators, hotels and other typical performances of the subsidiary caused by the case of breach of contract could understand as follows, due to the relative nature of the contract binding, when the assistant performer lead to personal injury, the tourism business operator should bear the liability for breach of contract, with the exception of public transport operators. In the specific lawsuit which the assistant performer lead to personal damage and property losses, the tourists have rights to choose the right between breach of contract and tort liability. In the light of the principle of breach of contract and the difficulty of the burden of proof, the tourist shall give have the right to claim damages for breach of contract when the tourists request the compensation for mental damage caused by the personal injury.
\end{abstract}

\section{Introduction}

In the course of the performance of the tourism contract, due to improper operation of the scenic area and facilities caused personal injury or death, public transport operators lead to personal damage to tourists by traffic accidents, the hotel reduce service standards and so on, which all against the legitimate rights and interests of tourists. Not only seriously infringe the personal interests of tourists and property losses, but also undermine the entire tourism market and tourism operators to bring great trouble.

Although China's "Tourism Law" has made clear provisions on this issue, but because the inevitable regulation of the law itself and the legislative technology cannot overcome the cognitive deficiencies, in the judicial practice legislation, which need to explain for application, through legal analogy to find the strongest reason of the parties to bear liabilities. From the existing legislation, through the tourism contract in the performance of the typical performance of the case to help analyze the case, this paper attempts to find out what liabilities all parties should bear in performance of the tourism contract. 


\section{First, the Basic Theory of the Assistant Performer in Tourism Contract}

In the field of contract law, it is controversial that the payment of the liability of the debtor in respect of the breach of liability caused by the third party, due to the reasons for the third person the debtor cannot be achieved payment, including the situation improper performance by the assistant performer.

On the basis of the theory that the assistant performer is the assistant to perform the debt, the reasons for which there are two: first reason from the law, second reason for the debtor's meaning. In modern civil law, in addition to some of the personal nature of the debt or a special agreement between the parties, the debt in principle can be carried out by a third party, without the need to obtain the consent of the creditors in advance only a number of contracts with exceptions, If the servant does not agree with the employer, the third party shall not be required to serve the service because the payment of the labor service is exclusive, and the parties may also agree that the debt shall not be fulfilled by the third party.

"Assistant performer" refers to a legal person or natural person that maintains a contractual relationship with a travel agency, assists the travel agency in fulfilling its obligations stipulated in a tourism contract, and the existence of a contractual relationship with the travel agency to help them fulfill the obligation to offer tourism contract, the actual provision of related services, common scenic spots and operators providing transportation, accommodation, catering, shopping and entertainment services are including in the tourism contract.

\section{Second, the Liabilities-Bearing of the Scenic Spot as the Assistant Performer}

When the scenic spot as the assistant performer in the tourism contract, how to bear the liabilities for breach of contracts, the current Chinese law has expresses explicitly.

According to the first provisions of Article 71 of the Tourism Law of the People's Republic of China, scenic spot is assistant performer in the tourism contract, in accordance with the constituent elements of breach of contract, when the behavior of scenic spots caused by tourists accidents and thus lead to the occurrence of breach of contract, travel business operator shall bear liability for the breach of contract caused by the assistant performer, at the same time, travel business operator may recover compensations from the assistant after fulfilling the liability.

However, paragraph 2 also provides that, as a result of the performance of the assistant performer to cause personal damage to the tourist, tourists may also choose to undertake responsibility for the performance of the assistant performer. In the judicial practice, the performance cause of personal injury caused by the assistant performer, the tourists enjoy the right to choose the defendant, according to "the Supreme People's Court on the trial of tourism disputes in the application of legal issues" Article 14, paragraph 1: "Tourists may require the assistant performer to bear tort liability for compensation for personal injury or property loss to the tourists caused by the assistant performer, the people's court should support. From the specific cases we could see that the performance of tourism contract shall have competent liabilities between breach of contract liability and tort liability, which gives tourists the right to choose. If the tourists do not consider the compensation on mental damages and choose the breach of contract liability, the tourists should first seek compensation from the organizing travel agency, the organizing travel agency shall bear liabilities and then ask the assistant performer to recovery. 


\section{Third, the Liabilities-Bearing of the Public Transport Operators as the Assistant Performer}

Generally speaking, the principle of imputation of strict liability of contract law does not require fault, its substantive spirit requires the parties to the contract should strengthen the sense of risk and contract spirit, the serious consequences is not in line with the "Tourism Law" in the "proviso" standard benchmark, as a subsidiary of the public transport operators to carry out the major mistakes cannot eliminate the responsibility of tourism business operators, based on the principle of fairness liability considerations, tourism business operators need to assume some responsibility, travel agencies and perform the auxiliary of common bear civil liability to compensate for many people's person injury and property losses according to the proportion.

When the public transport operators as the assistant performer in the tourism contract, tourists could ask the compensations, the current Chinese law has expresses in light of the breach of public transport operators.

Article 18 of the "Judicial Interpretation of the Supreme People's Court in the Trial of Tourism Disputes" provides a detailed description of the problems of public transport operators and tourism business operators, and expresses their support for the fact that the tourists request the tourism business operators to refund the unreasonable expenses. However, the "public transport operators" in Article 18 is a prerequisite for limited interpretation. It is limited to fixed-shift operations of public transport operators, which is distinguished from the independent contractual relationship between tourism business operators and public transport operators. In fact, public transport operators (Such as ships, airplanes, trains, tourism buses, intercity passenger trains, etc.) have been outside the scope of the control of the tourism business operator, but in the contract the tourism business operators can act on their own, In which the public transport operator is the role of the assistant performer, according to the theory of "the possibility of intervention", the public transport operator is an independent legal person and is an exclusive enterprise, Tourism business operator do not need to be responsible for their actions.

As a separate operation of the tourism business of the tourist bus has an exclusive nature of the enterprise characteristics, but also it has the independent commitment to the legal personality of the compensation, in the course of travel after the traffic accident, the law needs public transport operators to assume liability for breach of contract for tourist. Although the "proviso" of Article 71 of the Tourism Law is strictly responsible for the public transport operators, the tourism business operator needs to bear the responsibility of assisting the settlement.

In addition, China's tourism contract in the performance of travel agency compulsory liability insurance system. It is note that travel insurance liability does not distinguish between no fault liability and fault liability, causing heavy casualties, even the travel agency has no fault, but also should bear the liability, then the insurer must be "no compensation", it is the reason they shall bear the fair responsibility to share the loss between insurer and travel agency, that is, the travel agency and the insurer both share the responsibility.

\section{Fourth, the Liabilities-bearing of the Hotels as the Assistant Performer}

Specifically, concerning accommodations in tourism contract, tourism business operators shall ensure that the hotel has no flaw concerning legal obligations, the hotel is breaching the contract obvious in the performance of the assistant performer as follows: unauthorized reduction of accommodation standards and temporary to 
improve accommodation prices, which is very common in tourism activities, Travel agents in the tourism contract for the responsibility of the flaws, the travel agency should bear due to the hotel's tourism defects caused by breach of contract responsibility, according to China's "Tourism Law" Article 71, paragraph 1, the travel agency can take responsibility to the hotel after the recovery. At the same time, the rush travel season will inevitably lead to the hotel market bullish and accommodation beds tension, it is a pre-foreseeable fact, rather than force majeure, the liability of hotel cannot be a matter of exemption.

\section{Fifth, the Liabilities-bearing of Tourism Contracts in the Compensation for Mental Damage}

From the choice of the victims of mental damages relief, breach of contract mental damages has great advantages, because the liability for breach of contract on the inherent interests of tourists and tort liability on the personal interests of the same, we can see that the main difference between the two is the principle of imputation, the imputation of mental damages on breach of tourist contract is the principle of non-fault liability contract, the imputation of mental damages on tort liability is the principle of fault liability. If the tort liability law can impose the principle of no-fault liability for mental damages, it can also achieve the same relief as the liability for breach of contract, but the breakthrough in the principle of fault liability must have special reasons. For the tourism contract, the diversity of the main participation and the comprehensive nature of the transaction is a big feature. The diversification of the subject leads to the complexity of the transaction, the complicated legal relationship and the corresponding complexity of the rights and obligations. In the face of legal relief with the same effect, some of the parties will choose the mental damages of breach of contract liability for relief.

\section{Conclusions}

Through the scenic spot, public transport operators and hotels and other typical performance of the subsidiary caused by wrongful. It is very complicated to distinguish that the responsibility of the assistant performer in the performance of the tourism contract. The general design of the current legislation is to abide by the principle of contract relativity and strict liability. Based on the balance of interests and the value of the contract, the performance of the assistant performer should bear the responsibility for breach of contract, but one side we should pay attention which the alternative responsibility should not be infinitely enlarged, the scope of the contract should be bounded. In view of the particularity of the nature of the tourism contract, and another side we should aware the basis of the right of claim and the tort liability, the principle of imputation is different from liability of breach of contract, and the compensation for the breach of contract in the tourism contract is more favourable to the tourists. The legislation and cases change from negative to affirmative and more and more domestic scholars favour the breach of contract.

\section{Acknowledgments}

This work was financially supported co-founded by Hainan Social Science Association and Hainan Law Society fund project of (hnfh2016b10). 


\section{References}

[1] Tourism Law of the People's Republic of China (Adopted at the 2nd Meeting of the Standing Committee of the Twelfth National People's Congress on April 25, 2013).

[2] Judicial Interpretation of the Supreme People's Court in the Trial of Tourism Disputes in China (adopted on October 26, 2010).

[3] X.M. Xi: the Supreme People's Court trial of tourism disputes case of judicial interpretation and application (People Court Press, China, 2010.

[4] "Tourism Law of the People's Republic of China" of interpretation preparation group: "Interpretation on Tourism Law of the People's Republic of China" ( China Tourism Press, China, 2013).

[5] S.X. Peng: "On the Debtor of the Performance of the Assistant Performer", contained in "Journal of Beijing Institute of Technology in Chinese (Social Science Edition)" Volume 8, (2006) No. 2, April.

[6] J.Y. Zhang: "the Third Party Interests of the Contract on the Basis of the Will", contained "Tsinghua Law" 2008 the third period in Chinese.

[7] Q.Z. Lv: "Theoretical Study of the Relationship between the Contract", Tsinghua University doctoral thesis, 2006 in Chinese.

[8] C.N. Li: "Cross-strait Tourism Norms of the Study - to Consumer Protection as the Center", Taipei University Department of Law general student group master's thesis, 2015 in Chinese.

[9] S.H. Chen: "Research on Liability Damage of Travel Business Operators", Taiwan Fu Jen Catholic University Institute of Law Master thesis, 2010 in Chinese.

[10]H.Y. Xu: "Research on Tourism Contract", Taiwan Political University Law Research Institute Doctoral Thesis, January 1998, P1-6 in Chinese.

[11] Mark Posti waiting, Pan Jing translation: "Tourism Law Principles and Cases", Electronic Industry Press, 2004 edition in Chinese. 